\title{
Monitoring of radionuclide contamination of plants in the western part of Volyn Polissya (Ukraine) during 1994-2007
}

\author{
V.A. Hrabovskyy, O.S. Dzendzelyuk and O.S. Kushnir \\ Electronics Department, Lviv Ivan Franko National University 107 Gen. Tarnavsky St., \\ 79017 Lviv, Ukraine \\ e-mail: grabovsky@electronics.wups.Iviv.ua
}

\begin{abstract}
We present the main results of our more than decade-long monitoring of ${ }^{137} \mathrm{Cs}$ content in berry plants and medical herbs growing in the Shatsk National Natural Park (Volyn Region, Ukraine). It is shown that the ${ }^{137} \mathrm{Cs}$ content for most of the medical herbs has significantly decreased during the monitoring time period and now it meets the demands of Ukrainian sanitary standards (less than $200 \mathrm{~Bq} / \mathrm{kg} \mathrm{d}$. w.). The decreasing rate is much higher than that for the corresponding soils. This is because the radionuclide available in the soil becomes less accessible for digesting by the plant rootage in the course of time. The ${ }^{137} \mathrm{Cs}$ content in the vegetative and generative organs of bilberry shows essential seasonal variations. The corresponding content for the foliage reveals almost double decrease during the period when the berries ripen and an increase occurring after fructification.
\end{abstract}

\section{INTRODUCTION}

Radiologic studies of flora have become especially urgent after the Chornobyl disaster. During more than twenty years, these studies have been attracting permanent attention of researchers, both from the countries that have suffered most of all from the post-Chornobyl fallouts (Ukraine, Byelorussia and Russia) and from many other regions of the world. This interest is caused by the fact that entrance of radionuclides via typical food chains represents a crucial point in contaminating human organisms and so their internal irradiation. In its turn, contamination of foodstuff is now associated mainly with transition of radionuclides from soil to plants. The processes of accumulation of radionuclides from the soils taking place in the plants depend on many factors [1]. In particular, they are determined by specific kinds of radioisotopes, their amounts and states in the near-root layer of the soil (exchanging, nonexchanging or fixed). Again, the states mentioned above are dependent on the type of soil, its physical, chemical content and grading, acidity, amount and type of moistening, as well as availability in the soil of the closest chemical analogues of the radionuclide. Of importance are also some features of the depth distribution of radionuclide in the soil, together with species of the plant itself [2-4]. All of those factors may lead to essential discrepancies in the experimental results derived for radionuclide contamination of representatives of a given plant in different regions. The same also refers to the plants that belong to different species, though grow in the same region [2-4]. Of course, the radiologic studies enable estimating the level of radioactive contamination of the plants only in a specific place and under specific conditions. Nonetheless, they facilitate forecasting time evolution of the contamination.

The mentioned studies are all the more important for the contaminated territories of Ukrainian Polissya, since about a quarter of radiocaesium amount entering into organisms of people living on those territories is caused just by the berries used for food [5]. In general, the contribution of wild mushrooms and berries to the internal irradiation of the population of this region may reach $75-80 \%$ of the overall internal irradiation linked to the foodstuff [6].

Our choices of the place (Shatsk National Natural Park abbreviated as ShNNP, which is situated in the Volyn Region) and the objects of inquiry (berry plants and medical herbs) are justified by the 
following considerations. First, virtually all the Western Ukrainian Polissya represents a territory where wild forest berries and medical herbs are purchased commercially. The region has suffered more or less from the failure occurred at the Chornobyl Nuclear Plant, though the territory of ShNNP is not too much contaminated and, anyway, it is not admitted as being radio-contaminated. On the other hand, the main features of the nature and climate of the Park are typical for the Polissya. This is why the experimental results obtained for the Park might, in principle, be utilised for evaluating radiologic state of the entire region and forecasting its time evolution. Furthermore, important recommendations might follow regarding the prospects of the Park and economic utilization of contaminated territories of the Polissya in general.

\section{EXPERIMENTAL TECHNIQUES}

We studied a row of samples of both the plants and the soils, where the plants grow. The samples used for determining the contents of radionuclides (the so-called contamination density of the soil) in the upper $20 \mathrm{~cm}$-thick layer of the soil were prepared to analysis according to standard techniques (see [7]). Preparations of plant samples for quantitative gamma-analysis included their clearing of external impurities, separation of their vegetative and generative organs, then fragmentation, drying, grinding and homogenization. A necessary quantity of sample was weighted, packed into a special chamber and placed into measuring camera of gamma-spectrometer.

Qualitative and quantitative analyses of the samples were carried out at the accredited research laboratory (Nonlinear Optics Faculty, Lviv National University). This was done with a gammaspectrometer built on the basis of spectrometric complex SU-01F, using a semiconductor Ge(Li) detector DGDK-100 V (the resolution $2.5 \mathrm{keV}$ at $1332 \mathrm{keV}$ ). The radioactive background was eliminated with the aid of $10 \mathrm{~cm}$ thick lead housing that screened the measuring chamber of the spectrometer. The measurement technique applied by us allowed obtaining the final results with the errors not exceeding $\pm 15 \%$ for the specific activity.

\section{RESULTS AND DISCUSSION}

The studies of radiocaesium contamination of plants show that different species demonstrate different powers to assimilate the radionuclide from soil. In case of the plants manifesting great radiocaesium accumulation power, the latter quantity is gradually reduced with the passage of time. In particular, a number of representatives of the berry plants and some of the medical plants (i.e., heather and crystal tea ledum) refer to this group.

The level of ${ }^{137} \mathrm{Cs}$ contamination of plants is species-dependent and, moreover, it depends on the weather conditions of the vegetation period and some physiologic and biochemical conditions of the plant $[8,9]$. Penetration of radionuclides into above-ground organs of plants is tightly linked to absorption of moisture by the plants. Therefore, regardless of specific mechanisms of the penetration of radionuclide from the soil to the root system, the nuclide is further redistributed from the roots to vegetative and generative organs only at those places where the roots take in moisture. Besides, transition of radionuclides into plants substantially involves not only a direct coupling but also a corresponding feedback related to active influence of plants upon the mobility of pollutants [9]. It is interaction between the soil and the root system of plants that determines the effective (i.e., really accessible for absorption) amount of mobile fraction of the radionuclides. Thus, this interaction essentially affects the radionuclide accumulation of the plants.

The results obtained for the ${ }^{137} \mathrm{Cs}$ contamination of different species of medical herbs growing on the territory of ShNNP show that the radiocaesium content for the majority of plants does not exceed the sanitary standards functioning in Ukraine in the present time (i.e., the level of $200 \mathrm{~Bq} / \mathrm{kg}$ of dry weight (d. w.) - see [10]). The exceptions are legumes, foliage and berries of bilberry, red cowberry, bog bilberry, heather and crystal tea ledum. Besides of ${ }^{137} \mathrm{Cs}$, we have identified ${ }^{40} \mathrm{~K}$ in all of the 
medical herbs. Moreover, some of the herbs also reveal negligible quantities (the activities less than $40 \mathrm{~Bq} / \mathrm{kg} \mathrm{d}$. w.) of elements belonging to the natural uranium and thorium radioactive rows, together with ${ }^{7} \mathrm{Be}$. The latter appears in the atmosphere under the action of cosmic radiation and can enter the plant tissue due to aerial absorption and from the soil. The highest accumulation level of ${ }^{7} \mathrm{Be}$ is marked for the St.-John's wort $(160 \mathrm{~Bq} / \mathrm{kg})$, the heather $(185 \mathrm{~Bq} / \mathrm{kg})$ and the willow-herb $(200 \mathrm{~Bq} / \mathrm{kg})$. The activities of ${ }^{7} \mathrm{Be}$ remain in the limits of $70-90 \mathrm{~Bq} / \mathrm{kg}$ for the mullein, milfoil and the leaves of bilberry and bog bilberry. At last, the radionuclide has not been virtually revealed in the nettle and the leaves of cowberry.

In order to estimate contamination of plants caused by radiocaesium, the researchers often use the so-called transfer factor (abbreviated as TF and expressed often in $\mathrm{m}^{2} / \mathrm{kg}$ ):

$$
\mathrm{TF}=A_{P} / S_{S}
$$

where $A_{p}$ denotes the specific activity of the radionuclide referred to dry weight of the plant $(\mathrm{Bk} / \mathrm{kg})$ and $S_{S}$ is the contamination density of the soil $\left(\mathrm{kBk} / \mathrm{m}^{2}\right)$ (see $\left.[1,2]\right)$.

One has to take into account that the transfer factor for the soil-to-plant transition of radiocaesium is determined by a mobile part of the radionuclide content, which is easily accessible for assimilation, rather than a total content of the radionuclide available in the near-root layer of soil [1,9]. Obviously, this point can explain the fact that the contamination levels for the same species of medical herbs notably differ from each other, depending on the place of growth. The other reason may be mosaic character of the soil contamination $[2,4]$.

As mentioned above, some data support a concept of active reverse influence of the plants themselves upon the mobility of isotope-pollutant in the soil. These data certify that the accessibility of radiocaesium for the plants depends not only on their features and on the type of the corresponding soil. It is additionally determined by the density that characterises covering of the soil surface by the given plant. According to the data [9], the TF measured for the same soil becomes almost twice as much due to four-fold increase in the density of plants. This means that any categorization of the plants according to their level of ${ }^{137} \mathrm{Cs}$ accumulation is conditional. Nonetheless, it remains useful, since enables estimating a possible level of radionuclide accumulation by the given plant provided that the contamination of the corresponding soil is known.

In Table 1 we have gathered the data on ${ }^{137} \mathrm{Cs}$ contamination for the generative and vegetative organs of different representatives of the bilberry family. The data refer to a berry-field located near Pisochne Lake on the territory of ShNNP. The appropriate transfer factors are also depicted in Table 1.

Table 1. Specific activities $A(\mathrm{~Bq} / \mathrm{kg})$ of ${ }^{137} \mathrm{Cs}$ for the vegetative and generative organs of red cowberry, bilberry and bog bilberry taken from the ShNNP and the transfer factors TF $\left(\mathrm{m}^{2} / \mathrm{kg}\right)$ calculated for those organs (the data correspond to July, 2005; the error is less than $\pm 15 \%$ ).

\begin{tabular}{|c|c|c|c|c|c|c|}
\hline \multirow{3}{*}{ Organs of plants } & \multicolumn{6}{|c|}{ Object under studies (dried) } \\
\cline { 2 - 7 } & \multicolumn{2}{|c|}{ Bilberry } & \multicolumn{3}{c|}{ Bog bilberry } & \multicolumn{3}{c|}{ Red cowberry } \\
\cline { 2 - 7 } & $A_{p}$ & $\mathrm{TF}$ & $A_{p}$ & $\mathrm{TF}$ & $A_{p}$ & $\mathrm{TF}$ \\
\hline Berries & 208 & 62 & 249 & 74 & 408 & 121 \\
\hline Foliage & 333 & 99 & 371 & 110 & 213 & 63 \\
\hline Stems & 127 & 38 & 134 & 40 & 145 & 43 \\
\hline Roots & 181 & 54 & 170 & 51 & 138 & 41 \\
\hline
\end{tabular}

The maximum ${ }^{137} \mathrm{Cs}$ content observed for the bilberry and bog bilberry is typical of their foliage, while the minimum one - for the stems. This agrees with the data known from the literature [1, 2, 4, $11,12]$. The values of TF for the organs of bilberry and bog bilberry correlate well, thus testifying similarity of the processes of radionuclide accumulation typical for those whortleberries. The different 
data obtained for the red cowberry are evidently caused by some physiological peculiarities of that species. Namely, the bilberry and bog bilberry are deciduous shrubs, while the red cowberry represents an evergreen plant $[12,13]$. Accordingly, the metabolic processes taking place in their organs must be somewhat different.

The results for the time dynamics (during 1996-2007) of radiocaesium contamination characteristic of the organs of bilberry, bog bilberry and red cowberry taken from the ShNNP are shown in Table 2. The samples have been taken each year, in the first half of July. Table 2 depicts also the amount of atmospheric precipitates during April-July of those years. It is seen that the ${ }^{137} \mathrm{Cs}$ accumulation levels fall with time. Really, during the observation time period we have detected experimentally a significant decrease of that level for all of the plant species under study. Furthermore, the differences among the contents obtained for different species have been notable in the beginning of our monitoring and have reduced to a minimum in the most recent years.

Table 2. Changes in the specific activity of ${ }^{137} \mathrm{Cs}\left(A_{p}, \mathrm{~Bq} / \mathrm{kg} \mathrm{d}\right.$. w.) for different organs of red cowberry, bilberry and bog bilberry occurring in the course of time (the data correspond to the first half of July).

\begin{tabular}{|c|c|c|c|c|c|c|c|c|c|c|c|c|}
\hline \multirow[b]{2}{*}{ Organs of plants } & \multicolumn{12}{|c|}{ Years } \\
\hline & 1996 & 1997 & 1998 & 1999 & 2000 & 2001 & 2002 & 2003 & 2004 & 2005 & 2006 & 2007 \\
\hline \multicolumn{13}{|l|}{ Bilberry: } \\
\hline Berries & 512 & 565 & 586 & 436 & 390 & 373 & 308 & 276 & 243 & 208 & 215 & 224 \\
\hline Foliage & 967 & 830 & 713 & 648 & 644 & 587 & 430 & 331 & 284 & 327 & 367 & 305 \\
\hline Stems & 418 & 430 & 482 & 357 & 222 & 290 & 124 & 162 & 140 & 127 & 139 & 129 \\
\hline Roots & 681 & 462 & 391 & 290 & 228 & 230 & 179 & 205 & 176 & 181 & 151 & 113 \\
\hline \multicolumn{13}{|l|}{ Bog bilberry: } \\
\hline Berries & & & & 318 & 291 & & 322 & 269 & 241 & 249 & 288 & 141 \\
\hline Foliage & 603 & 538 & 408 & 363 & 360 & 417 & 288 & 283 & 331 & 333 & 226 & 327 \\
\hline Stems & 248 & 162 & 128 & 134 & 131 & 95 & 166 & 150 & 179 & 134 & 144 & 127 \\
\hline Roots & 466 & 400 & 315 & 291 & 220 & 277 & 302 & 232 & 226 & 170 & 202 & 140 \\
\hline \multicolumn{13}{|l|}{ Red cowberry: } \\
\hline Berries & & & & & & & 531 & & & 213 & 312 & 310 \\
\hline Foliage & & & 605 & 703 & 495 & 460 & 420 & 340 & 374 & 146 & 196 & 187 \\
\hline Stems & & & & & 368 & 460 & 206 & 228 & 227 & 102 & 111 & 130 \\
\hline $\begin{array}{l}\text { Atmospheric } \\
\text { precipitates* }\end{array}$ & 261 & 284 & 545 & 247 & 294 & 541 & 132 & 265 & 186 & 240 & 179 & 285 \\
\hline
\end{tabular}

* The atmospheric precipitates during April-July of every year, in mm (according to the data of Svityaz hydrometeorological station of Shatsk District, Volyn Region).

One can observe some deviations of decreasing radionuclide content in the foliage from the monotonous one, which are peculiar for a number of years. Obviously, investigations of the foliage of different ages might partly explain these facts. Indeed, the ${ }^{137} \mathrm{Cs}$ activities determined in the midst of July, 2007, for the young and old bilberry leaves are respectively equal to $198 \mathrm{~Bq} / \mathrm{kg}(342 \mathrm{~Bq} / \mathrm{kg})$ and $86 \mathrm{~Bq} / \mathrm{kg}(265 \mathrm{~Bq} / \mathrm{kg})$, where the figures in parentheses refer to another berry-field in the ShNNP. This agrees well with the data $[11,12]$. Another reason may be an effect of climate and weather factors. In this respect, the authors $[2,9,14]$ have pointed out that the accumulation levels of radioactive caesium observed for the stems, foliage and berries of the berry plants can vary, depending on the climate conditions. In particular, the ${ }^{137} \mathrm{Cs}$ content in the bilberry stems in cool and humid years can even exceed that for the berries.

The influence of vegetation conditions, first of all the soil humidity, upon the radionuclide content in the berries of the berry plants are clearly seen from Table 2. Against the background of continuous decrease of the radiocaesium content for all the other bilberry organs, the radionuclide content in its berries partly increased in 1996-1998 and then began to decrease substantially. A similar dependence observed in the work [2] has been explained by both higher humidity of the soils in the years of intense accumulation of radionuclide by the bilberry berries (see the amount of atmospheric precipitates in 
Table 2) and its additional entrance into the soil originated from the forest bedding (i.e., from decaying needles contaminated by Chornobyl fallouts). In arid and hot seasons, the berries become ripe earlier. Let us take into account a decrease of the radionuclide content in the berries during the process of their ripening, which has been pointed to in the work $[11,12]$. Then the increased ${ }^{137} \mathrm{Cs}$ activity for the berries taken in the same time of more humid and cooler years becomes quite understandable. At last, seasonal dependence of the radionuclide content in the organs of plants (see Fig. 1) might be a second reason for this effect.

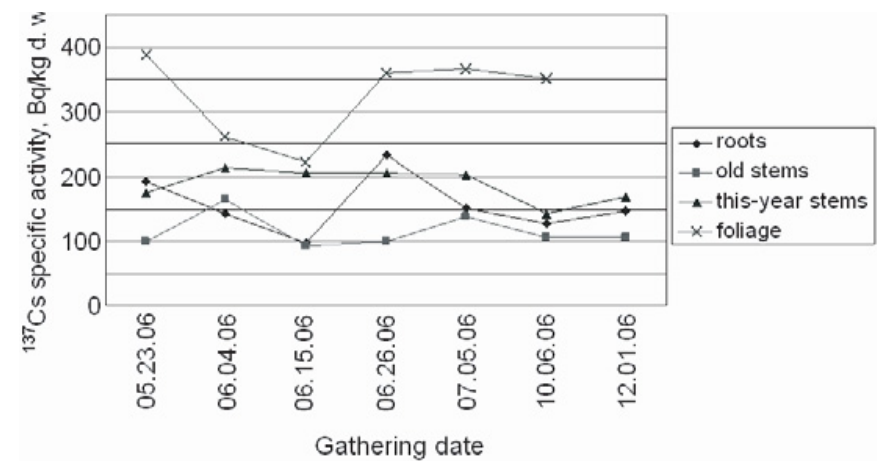

Figure 1. Seasonal dependences of ${ }^{137} \mathrm{Cs}$ content (from May to December 2006) for different vegetative organs of bilberry taken from the ShNNP.

The seasonal variations of ${ }^{137} \mathrm{Cs}$ content accumulated by the vegetative organs of bilberry agree well with the course of pheno-phases of this plant. For instance, on the territory of Ukrainian Polissya the florescence process for the bilberry ends (i.e., the fructification begins) in the middle of May or in the second half of May, while the ripening of the berries lasts until the end of June [12]. As seen from Fig. 1, the radiocaesium content in the foliage, roots and perennial stems of the plant notably decreases just during this period. Only this-year stems manifest no essential changes in the nuclide content. Obviously, these changes of the radionuclide content in the vegetative organs of bilberry could be associated with transfer of ${ }^{137} \mathrm{Cs}$ from those organs to the berries while the latter are forming and ripening. Besides, short-time (one- or two-week long) shifts of the corresponding cycles, which are produced by the climate features of humid and arid years [11, 12], also contribute to the seasonal variations of radionuclide accumulation by different organs of the plants.

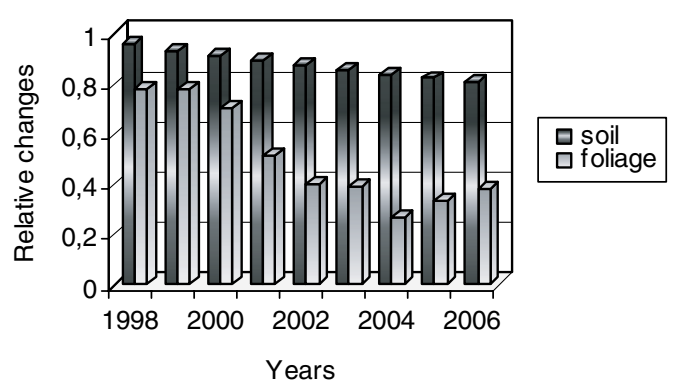

Figure 2. Time dependences of normalised contents of ${ }^{137} \mathrm{Cs}$ in the bilberry foliage and the corresponding soil.

The analysis for the time variations of the relative radiocaesium content for the bilberry foliage and the soil of the berry-field (see Fig. 2) shows that the contamination level for the plant organs decreases much more rapidly than that typical for the soils where they grow on. Indeed, the content of ${ }^{137} \mathrm{Cs}$ in 
the soil has decreased by about $20 \%$ during 1998-2006, the main cause being its natural decay. At the same time, the ${ }^{137} \mathrm{Cs}$ content in the vegetative organs has decreased more than twice in the same period. Therefore, we have decreasing transfer factor that describes transition of the radionuclide from the soil to the given organ or the overall plant. A large difference between the time variations of radionuclide contamination of the berry plants and the corresponding soils may be evidently linked to "ageing" of the radionuclide. This means locking in of the radionuclide at the soil complexes (mainly clay and humus ones), the effect becoming more intense in the course of time. Then the nuclide becomes less accessible for digestion by the rootage, though remaining in the near-root layer of the soil $[9,15]$. One can naturally suppose that this tendency for the contaminated territories of the Polissya will be kept in the future. Then the contamination of wild plants would drop and go well into the levels permitted by the Ukrainian sanitary standards [10] much more rapidly than the contamination of the soils. This implies real possibilities for industrial utilization of the plants as raw materials for the food and pharmaceutical industries, of course, under the conditions of a proper preliminary radiologic monitoring.

\section{References}

[1] Aleksakhin R.M., Vasilyev A.V., Dikaryev V.G., et al. (1992) Agricultural radioecology (Ed. by Aleksakhin R.M. and Korneyev N.A.) Moscow: Ekologiya (in Russian).

[2] Krasnov V.P. (1998) Radioecology of the forests of Ukrainian Polissya. Zhytomyr: Volyn (in Ukrainian).

[3] Ipatyev V.A. et al. (1999) Forest. Man. Chernobyl. Forest ecosystems after the failure at the Chernobyl Nuclear Power Plant: state, prognosis, reaction of population and ways for rehabilitation (Ed. by Ipatyev V.A.). Gomel: Institute of Forestry of Byelorussian National Academy of Sciences (in Russian).

[4] Perevolotskiy A.N. (2006) ${ }^{137} \mathrm{Cs}$ and ${ }^{90} \mathrm{Sr}$ distribution in the forest biogeocenosis. Gomel: RNIUP "Institute for Radiology" (in Russian).

[5] Kenigsberg Y.E. and Buglova E.E. (1994) Dose formation of internal exposure according to peculiarities of caesium radionuclides transfer by food chain and efficiencies of countermeasures. In: Belarus-Japan Symposium "Acute and Late Consequences of Nuclear Catastrophes: Hiroshima-Nagasaki and Chernobyl” pp. 82-96. Proceedings, Minsk.

[6] Orlov A.A. (2001) Accumulation of man-caused radionuclides by wild berry plants of forests, Chernobyl Digest'98-2000. Vol. 6. Minsk (in Russian).

[7] Methodical recommendations for evaluating radiation state in the settlements which are situated inside the area of radioactive contamination and have the average density of caesium-137 up to $5 \mathrm{Ki} / \mathrm{m}^{2}$. (1991) Kyiv: UMKRK (in Russian).

[8] Prister B.S., Omelyanenko N.P. and Perepelyatnikova L.V. (1990) Migration of radionuclides in soil and their transfer into plants inside the area of disaster at the Chernobyl Nuclear Plant // Pochvovedeniye 10, 51-60 (in Russian).

[9] Kravets O.P. (2001) Radioecological aspects of formation of radionuclide flowss into "Soil-Plant" system. Abstract of Doctor of Sciences Dissertation in biology. Kyiv (in Ukrainian).

[10] Permissible levels for the content of ${ }^{137} \mathrm{Cs}$ and ${ }^{90} \mathrm{Sr}$ radionuclides in foodstuffs and drinking water. (2006) Kyiv (in Ukrainian).

[11] Korotkova O.Z. (2000) Accumulation of ${ }^{137}$ Cs by the primary berry plants of Ukrainian Polissya: Abstract of Candidate of Sciences Dissertation in agriculture, Zhytomyr (in Ukrainian).

[12] Orlov O.O. and Korotkova O.Z. (2000) Peculiarities of seasonal dynamics of ${ }^{137}$ Cs accumulation by phytomass of bilberry (Vaccinium myrtillus L.) and red cowberry (Vaccinium vitis-idaea L.), Scientific Bulletin of Ukrainian National University of Forestry 10.2, 34-43 (in Ukrainian).

[13] Krasnov V.P., Orlov O.O. and Korotkova O.Z. (1996) Natural occurrence and production of wild berry plants belonging to red cowberry family in the forests of Ukrainian Polissya, Scientific Proceeding of Polissya ALNDS. Zhytomyr, 3, 48-54 (in Ukrainian). 
[14] Balonov M.I. and Travnikova I.G. (1990) The role of agricultural and natural ecosystems in the internal dose formation in the inhabitants of controlled area. In: Transfer of radionuclides in natural and semi-natural environments, pp. 419-430, London-New-York: Elsevier Applied Science.

[15] Levchuk S.E. (1995) The experimental examination and the mathematical modelling of migration processes of Chornobyl fallouts radionuclides in Ukrainian Polissya soils: Abstract of Candidate of Sciences Dissertation in biology, Kyiv (in Ukrainian). 
